Piotr Cebula

\title{
PRAWDOPODOBIEŃSTWO: DROGA DO PEWNOŚCI? PROBABILISTYKA W MYŚLI JOHNA HENRY'EGO NEWMANA
}

Prawdopodobieństwo jest przewodnikiem życia.

Joseph Butler

\section{WPROWADZENIE}

Rozpoczynając intelektualną przygodę z filozofią Johna Henry'ego Newmana, niemalże od razu spotykamy się w jego pismach z pojęciem prawdopodobieństwa, w różnych kontekstach i znaczeniach. Jak je rozumieć? Czysto potocznie czy w sposób zapętlony w teorie matematyczne? Jeżeli udałoby się odpowiedzieć na to pytanie, zaraz pojawia się kolejne: jaka jest rola prawdopodobieństwa w dążeniu do - bardzo istotnej dla Newmana - pewności?

Celem artykułu jest zmierzenie się z wymienionymi pytaniami. Nie będzie to jednak dogłębna analiza wspomnianych kwestii, lecz jedynie propozycja interpretacji powiązania pojęć prawdopodobieństwa i pewności w filozofii Newmana. Przedstawiony szkic może być więc punktem wyjścia do dalszych poszukiwań. Ukażemy najpierw inspiracje filozoficzne, które wpłynęły na myśl 


\section{PROBABILITY: WAY TO CERTAINTY? PROBABILITY IN NEWMAN'S THOUGHT}

\section{SUMMARY}

The term „probability” in Newman's philosophy is ambiguous. This fact, very often causes the chaos of interpretation. The second difficulty is to grasp the relationship between the probability and certainty-certitude in the system of its thought. The aim of this article is to try to solve these two matters. The way of using the word by the cardinal shows that it is an instrument of implicit reasoning and it has an epistemic meaning. The accumulation of probabilities brings us to assent something as the truth. However, they never extort for it. When in the province of implicit reasoning the assent is the fact, and is reflected upon, then the assent is the certitude. So, in Newman's thought probability is a natural way to certitude.

\section{KEYWORDS}

probability, certitude, Newman J.H. 